\title{
PEMBERDAYAAN IBU RUMAH TANGGA MELALUI PELATIHAN PEMBUATAN NUGGET KUPANG DI DESA KARANG GADING
}

\author{
Siti Zubaidah ${ }^{1}$, Ibnu hajar ${ }^{2}$ \\ Pendidikan Masyarakat Universitas Negeri Medan \\ sizudazuda@gmail.com
}

\begin{abstract}
Abstrak
Permasalahan pada penelitian ini yaitu banyaknya ibu rumah tangga yang memiliki waktu luang dan masih memiliki tingkat pendapatan yang cukup rendah serta kurangnya pengetahuan dan keterampilan ibu rumah tangga dalam mengolah hasil laut yang tanpa disadari bahwa potensi tersebut bisa menjadi peluang usaha yang dapat menambah pendapatan keluarga. Tujuan penelitian ini adalah untuk mendeskripsikan proses pemberdayaan ibu rumah tangga melalui pembuatan nugget kupang di desa Karang gading. Teori pemberdayaan yang digunakan adalah Mustafa Kamil (2007) Pelatihan adalah proses pemberdayaan dan pemberlajaran yang dilakukan oleh individu (anggota masyarakat) dalam mempelajari sesuatu guna meningkatkan kemampuan, keterampilan, dan tingkah laku dalam pekerjaan dan kehidupan sehari-hari dalam menopang ekonominya (pendapatan). Teori ini menerangkan bahwa pemberdayaan merupakan proses pemberian pengetahuan dan keterampilan kepada masyarakat dengan tujuan untuk meningkatkan kualitas hidup yang diharapkan jika keteramiplan tersebut direalisasikan akan menambah pendapatan keluarga. Penelitian ini merupakan penelitian deskriptif dengan menggunakan pendekatan kualitatif. Alat pengumpulan data yang digunakan adalah lembar observasi, wawancara dan dokumentasi. Teknik analisis data yang digunakan yaitu reduksi data, penyajian data, dan penarikan kesimpulan. Hasil dan pembahasan penelitian menjelaskan bahwa proses peltihan pembuatan nugget kupang dibagi menjadi tiga tahap yaitu tahap perencanaan, pelaksanaan dan evaluasi. Materi cara pengemasan dan pemasaran nugget kupang juga disampaikan dalam pelatihan tersebut.
\end{abstract}

Kata Kunci: Pemberdayaan, Pelatihan Pembuatan Nugget Kupang

\begin{abstract}
The problems in this study are the number of housewives who have free time and still have a fairly low income level and the lack of knowledge and skills of housewives in processing seafood without realizing that this potential can be a business opportunity that can increase family income. The purpose of this study was to describe the process of empowering housewives through making kupang nuggets in Karang Gading village. The empowerment theory used is Mustafa Kamil (2007). Training is a process of empowerment and learning carried out by individuals (community members) in learning something in order to improve abilities, skills, and behavior in work and daily life in supporting their economy (income). This theory explains that empowerment is a process of providing knowledge and skills to the community with the aim of improving the quality of life which is expected if these skills are realized will increase family income. This research is a descriptive study using a qualitative approach. Data collection tools used are observation sheets, interviews and documentation. Data analysis techniques used are data reduction, data presentation, and drawing conclusions. The results and discussion of the research explained that the training process for making kupang nuggets was divided into three stages, namely the planning, implementation and evaluation stages. Materials on packaging and marketing of kupang nuggets were also delivered in the training.
\end{abstract}

Keywords: Empowerment, Kupang Nugget Making Training 


\section{PENDAHULUAN}

Pemberdayaan masyarakat merupakan upaya untuk memberdayakan masyarakat yang karena ketidakmampuannya baik karena faktor internal maupun eksternal. Pemberdayaan diharapkan mampu mengubah tatanan hidup masyarakat kearah yang lebih baik, sebagaimana cita-cita bangsa untuk mewujudkan masyarakat yang adil, demokratis, sejahtera dan maju. Pemberdayaan (emvowerment) merupakan suatu proses yang ditujukan untuk membantu masyarakat untuk memperoleh daya (kuasa) untuk mengambil keputusan dan menentukan tindakan yang akan ia lakukan, termasuk mengurangi efek hambatan pribadi dan sosial dalam melakukan tindakan. Secara umum partisipasi perempuan di bidang ekonomi masih rendah, kemampuan perempuan memperoleh peluang kerja dan berusaha masih rendah, demikian juga terhadap akses sumber daya ekonomi. Kegiatan yang dilakukan ibu rumah tangga pada waktu luang seperti peneliti amati pada saat observasi antara lain membantu suami di sawah, dan mengupas kupang. Ketika musim bertani selesai maka pekerjaan mereka hanya mengupas kupang yang biasanya hanya dari jam 7 sampai jam 9 pagi saja. Para ibu rumah tangga di dusun XIII Pematang Pelik sendiri banyak mempunyai waktu kosong karena hanya bekerja sebagai ibu rumah tangga saja tentu penghasilan yang di dapat mereka kecil, apalagi kondisi ekonomi sekarang yang semakin sulit. Untuk itu perlu adanya perhatian khusus terhadap ibu rumah tangga Dusun XIII Pematang Delik. Dalam rangka pemberdayaan di bidang ekonomi pada ibu rumah tangga dari sisi usaha tambahan, maka perlu ditangani secara konpherensif. Penanganan kendala modal dan kendala distribusi tidak seluruhnya dapat dilakukan melalui pendekatan ekonomi semata. Desa Karang Gading tepatnya di Dusun XIII Pematang Delik letaknya dekat dengan bantaran sungai, warga bantaran sungai mayoritas bekerja sebagai nelayan kupang, kerang dan ikan. Namun kupang adalah hewan laut sejenis kerang yang khas, kupang hanya di jual dalam keadaan hanya direbus saja. Biasanya kupang diolah menjadi rendang, sambal ataupun hanya di goreng saja. Ibu-ibu rumah tangga Desa Karang Gading belum memiliki keterampilan dalam mengolah kupang menjadi cemilan yang bisa di konsumsi semua kalangan, seperti bakso dan nugget. Padahal jika mereka memiliki keterampilan mengolah dan memasarkannya bisa membantu perekonomian mereka dan makanan tersebut juga bisa menjadi oleh-oleh khas dari Desa Karang Gading. Selain itu makanan olahan seperti nugget dan bakso banyak digemari oleh semua kalangan. Berdasarkan hasil pengamatan peneliti menemukan bahwa di sekolah-sekolah makanan ini sangat banyak diminati. Melihat potensi kupang yang ada di Desa Karang Gading yang sangat besar, namun namun belum ada yang mengolahnya menjadi makanan yang hampir bisa dikonsumsi semua kalangan dan terkadang jika kupang tidak habi dipasarkan maka kupang tersebut akan membusuk. Untuk itu, sangat disayangkan apabila potensi kupang yang melipah hanya dijual secara mentah dan tidak diolah atau dikembangkan untuk menjadi lapangan kerja baru yang menjanjikan dan menyerap banyak tenaga kerja. penelitian ini dilakukan bertujuan untuk mendeskripsikan bagaimana pelaksanaan program pemberdayaan ibu-ibu rumah tangga melalui pelatihan pembuatan nugget kupang di Desa Karang Gading.

\section{KAJIAN TEORI}

\section{Pengertian Pemberdayaan}

Secara konseptual, pemberdayaan atau pemberkuasaan (empowerment) berasal dari kata 'power' (kekuasaan atau keberdayaan). Karenanya, ide utama pemberdayaan bersentuhan dengan konsep mengenai kekuasaan. Kekuasaan seringkali dikaitkan dengan kemampuan untuk membuat orang lain melakukan apa yang diinginkan, terlepas dari keinginan dan minat mereka. Ilmu sosial 
tradisional menekankan bahwa kekuasaan berkaitan dengan pengaruh dan kontrol. Pengertian ini mengasumsikan bahwa kekuasaan sebagai sesuatu yang tidak berubah atau tidak dirubah. Kekuasaan sesungguhnya tidak terbatas pada pengertian di atas. Kekuasaan tidak vakum dan terisolasi. Kekuasaan senantiasa hadir dalam konteks relasi sosial antar manusia. Kekuasaan tercipta dalam relasi sosial. Karena itu, kekuasaan dan hubungan kekuasaan dapat berubah (Suharto, 2010: 57-58).

Konsep pemberdayaan (empowerming) dalam pendidikan luar sekolah di Indonesia pertama kali dikembangkan oleh Kindervatter. Pemberdayaan sebagai proses pemberian kekuatan atau daya dalam bentuk pendidikan yang bertujuan membangkitkan kesadaran, pengertian dan kepekaan warga belajar terhadap perkembangan sosial, ekonomi, dan politik. Sehingga pada akhirnya memiliki kemampuan untuk memperbaiki dan meningkatkan kedudukannya dalam masyarakat (Kindervatter dalam Anwar, 2006: 77).

\section{Tujuan Dan Sasaran Pemberdayaan}

Tujuan yang ingin dicapai dalam pemberdayaan adalah untuk membentuk individu dan masyarakat menjadi mandiri. Kemandirian tersebut meliputi kemandirian berpikir, bertindak dan mengendalikan apa yang mereka lakukan tersebut. Kemandirian masyarakat merupakan suatu kondisi yang dialami oleh masyarakat yang ditandai oleh kemampuan untuk memikirkan, memutuskan serta melakukan sesuatu yang dipandang tepat demi mencapai pemecahan masalahmasalah yang dihadapi dengan menggunakan daya kemampuan yang terdiri atas kognitif, psikomotorik, efektif, dan pengarahan sumber daya yang oleh lingkungagn internal masyarakat tersebut (Teguh, 2004: 80). Disimpulkan bahwa upaya pemberdayaan masyarakat bertujuan untuk membuat masyarakat menjadi mandir, dalam arti memiliki kemampuan untuk memecahkan masalah yang mereka hadapi dan mampu memenuhi kebutuhan tanpa harus menggantungkan hidup mereka pada orang lain atau pihak luar. Sasaran pemberdayaan itu sendiri adalah masyarakat miskin yang dirasa belum mampu membangun diri mereka sendiri sehingga belum berdaya.

\section{Pengertian Pelatihan}

Menurut Sastrodipoero (dalam Kamil Mustofa, 2007: 152) mengatakan bahwa pelatihan merupakan salah satu jenis proses pembelajaran untuk memperoleh dan meningkatkan keterampilan diluar sistem pengembangan sumber daya manusia, yang berlaku dalam waktu yang relative singkat dengan metode yang lebih mengutamakan praktik daripada teori. Pelatihan adalah salah satu metode dalam pendidikan orang dewasa atau dalam suatu pertemuan yang biasa digunakan dalam meningkatkan pengetahuan, keterampilan, dan mengubah sikap peserta dengan cara yang spesifik. Istilah pelatihan merupakan terjemahan dari kata "training” adalah"train", yang berarti: 1) memberi pelajaran dan praktik (give teaching and practice), 2) menjadikan berkembang dalam arah yang dikehendaki (cause to grow in a qured direction), 3) persiapan (preparation), dan 4) praktik (practice) (Kamil , 2007: 3). Menurut Kamil (2012:12) menyebutkan bahwa pada dasarnya proses pelatihan mencakup tiga tahapan yaitu:

1. Perencanaan

2. Pelaksanaan

3. Evaluasi 


\section{METODE PENELITIAN}

Jenis penelitian ini merupakan deskriptif dengan menggunakan pendekatan kualitatif. Penelitian kualitatif yaitu sebuah penelitian yang menguraikan secara mendalam tentang apa yang diperoleh dari orang lain, baik dari kata-kata tertulis atau lisan dari orang-orang dan perilaku yang dapat diamati. Penelitian kualitatif disebut juga penelitian naturalistik. Disebut kualitatif karena sifat data yang dikumpulkan yang bercorak kualitatif, bukan kuantitatif, karena tidak menggunakan alat-alat pengukur. Disebut naturalistik karena situasi lapangan bersifat "natural" atau wajar. Sebagaimana adanya, tanpa dimanipulasi diatur dengan ekperimen atau test (Nasution, 2003: 18). Adapun tempat penelitian ini ini dilakukan di Dusun XIII Pematang Delik, Desa Karang Gading, Kecamatan Secanggang, Kabupaten Langkat. Dalam penelitian ini yang menjadi subjek penelitiannya adalah ibu rumah tangga yang ada di Dusun XIII Pematang Delik.

Dalam penelitian ini, proses pengambilan data dilakukan dengan menggunakan instrumen yaitu penelitian yang dibantu oleh pedoman observasi, wawancara dan dokumentasi. Masalah pencatatan dan wawancara juga merupakan suatu aspek utama dalam melakukan wawancara jika pencatatan tidak dilakukan dengan baik maka data juga tidak akan valid dan usaha wawancara yang dilakukan juga akan sia-sia. Selain dengan metode wawancara pengambilan data juga menggunakan metode dokumentasi, dengan mengumpulkan data-data yang dapat mendukung dalam melakukan penelitian.

Analisis data yang digunakan oleh penulis dalam penelitian kualitatif yaitu dengan menguraikan, menginterprestasikan data pada akhirnya diambil suatu kesimpulan dalam bentuk tulilsan dan sistematis. Analisis data kualitatif merupakan upaya yang berlanjut, berulang, dan terus-menerus. Penelitian ini menggunakan analisis data kualitatif. Oleh karena itu, langkahlangkah untuk melakukan analisis data menurut Miles dan Huberman, terdapat tiga teknik analisis data kualitatif yaitu reduksi data, penyajian data, dan penarikan kesimpulan (Bungin, 2011: 144).

\section{HASIL DAN PEMBAHASAN \\ HASIL}

1. Tahap Perencanaan dan Persiapan

Berdasarkan hasil observasi pada tahap persiapan peserta dalam mengikuti pelatihan berjalan baik. Pada hari Minggu 25 April 2021 pada pukul 14:00-15:30 Wib telah dilakukan tahap perencanaan

Tahap awal yang dilakukan yaitu sebagai berikut

- Menentukan peserta pelatihan

Peserta pelatihannya yaitu ibu rumah tangga yang ada di dusun XIII Pematang Delik yang memiliki kriteria yaitu tidak bekerja atau hanya mengurus rumah tangga.

- Setelah itu dilakukan diskusi, diskusi dilakukan untuk membuat logo kemasan, menentukan hari, lokasi dan waktu pelatihan, serta menentukan belanja bahan-bahan untuk pembuatan nugget kupang. Berdasarkan hasil diskusi yaitu pelatihan dilaksanakan pada hari Jumat 30 April 2021 lokasi pelatihan di rumah Bu Linda pada pukul 10:00 WIB s/d selesai. Yang bertugas membeli bahan-bahan untuk pelatihan yaitu Ibu Linda. 


\section{Tabel 1}

\section{Rancangan pelatihan}

\begin{tabular}{|l|l|l|}
\hline \multicolumn{1}{|c|}{ Jadwal Kegiatan } & \multicolumn{1}{|c|}{ Kegiatan yang Dilakukan } & \multicolumn{1}{c|}{ Tempat Kegiatan } \\
\hline $\begin{array}{l}\text { Minggu 25 April 2021 } \\
\text { Pukul 14:00-15:30 wib }\end{array}$ & Tahap perencanaan & Rumah ibu Linda \\
\hline $\begin{array}{l}\text { Selasa 27 April 2021 } \\
\text { Pukul 10:00wib s/d selesai }\end{array}$ & $\begin{array}{l}\text { Pelaksanaan pemilihan bahan bakl } \\
\text { yang baik }\end{array}$ & Rumah ibu Linda \\
\hline $\begin{array}{l}\text { Jumat 30 April 2021 } \\
\text { Pukul 10:00 wib s/d selesai }\end{array}$ & $\begin{array}{l}\text { Pelaksanaan pengolahan nugget } \\
\text { kupang serta praktek pengemasan } \\
\text { produk }\end{array}$ & Rumah ibu Linda \\
\hline $\begin{array}{l}\text { Sabtu 1 Mei 2021 } \\
\text { Pukul 10:00 wib s/d selesai }\end{array}$ & $\begin{array}{l}\text { Pelaksanaan cara pemasaran } \\
\text { produk }\end{array}$ & Rumah ibu Linda \\
\hline
\end{tabular}

2. Tahap Pelaksanaan

Pemahaman peserta terhadap pemilihan bahan baku, pengolahan nugget, pengemasan produk, dan penyampaian materi cara pemasaran produk sudah baik. Sebelum tahap pengolahan nugget kupang terlebih dahulu dilaksanakan pemilihan bahan baku yang baik. Tujuan dari tahap ini yaitu agar nugget yang dihasilkan memiliki kualitas rasa yang baik.

a) Pembuatan nugget

Proses pembuatan nugget ini dilakukan secara bersama-sama dengan peserta dan instruktur pelatihan.

\section{Tabel 3}

\section{Bahan dan alat untuk membuat nugget}

\begin{tabular}{|l|l|l|}
\hline No. & \multicolumn{1}{|c|}{ Bahan-Bahan } & \multicolumn{1}{|c|}{ Alat } \\
\hline 1. & $1 \mathrm{~kg}$ kupang & Panci kukusan \\
\hline 2. & 1 kg tepung terigu & Blender \\
\hline 3. & $1 / 2$ tepung tapioka & Pisau \\
\hline 4. & 5 siung bawang merah & Mangkok besar \\
\hline 5. & 5 siung bawang putih & Loyang kukusan \\
\hline 6. & 1 sendok teh merica & Talam \\
\hline 7. & Garam dan penyedap rasa secukupnya & Sendok \\
\hline 8. & Daun seledri dan daun bawang secukupnya & \\
\hline 9. & 3 buah wortel & \\
\hline 10. & Tepung panir $1 / 2 \mathrm{~kg}$ & \\
\hline 11. & Telur 2 butir & \\
\hline
\end{tabular}

- Mencuci kupang atau dibersihkan hingga beberapa kali sampai kupang benar-benar bersih.

- Kemudian memblender kupang bersamaan dengan bawang merah, bawang putih, merica, garam, dan penyedap rasa hingga benar-benar semua halus. 
- Setelah bahan semua halus adonan dimasukkan ke dalam mangkuk besar dan tambahkan parutan wortel, tepung terigu dan tepung tapioka, daun seledri, daun bawang dan telur sisakan tepung terigu sebagian untuk mengolesi panir. Aduk adonan hingga merata.

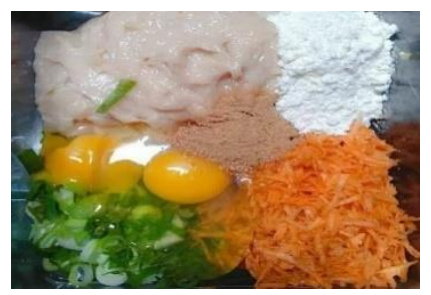

Gambar 1. Bahan-bahan sebelum diaduk

- Selanjutnya adonan dimasukan ke dalam loyang dan di kukus hingga matang. Langkahlangkah: instruktur mengintruksikan peserta untuk menyiapkan panci kukusan.

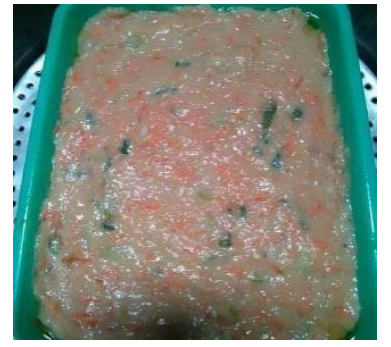

Gambar 2. Adonan akan dikukus

- Setelah matang dinginkan sebentar, lalu potong kecil-kecil seperti stik. Siapkan adonan tepung terigu, lalu potongan nugget tersebut dimasukan ke dalam adonan kemudian dilumuri dengan panir. Langkah-langkah: istruktur mengintruksikan agar peserta bersama-sama memotong nugget dengan rapi.
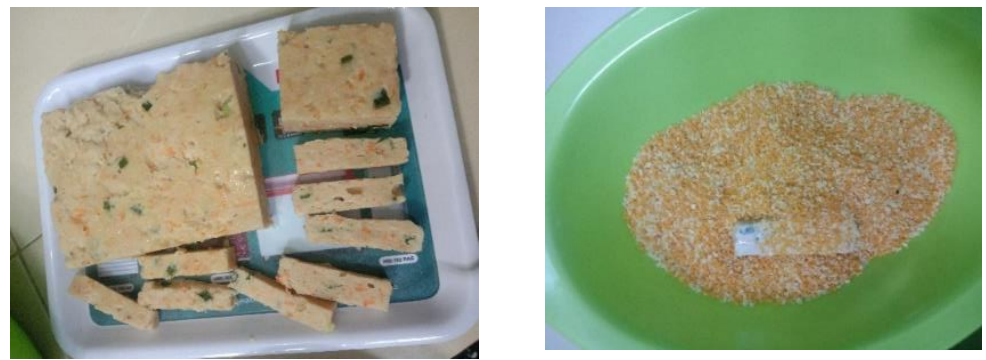

Gambar 4. Proses melumuri nugget dengan panir

b) Proses pengemasan

Setelah proses pembuatan nugget kupang selesai langkah selanjutnya yang dilakukan yaitu penyampaian cara pengemasan nugget kupang agar terlihat bagus dan menarik dengan menggunakan logo. 1 kemasan nugget kupang berisi 20 biji. Berdasarkan hasil observasi praktek pengemasan produk cukup. 

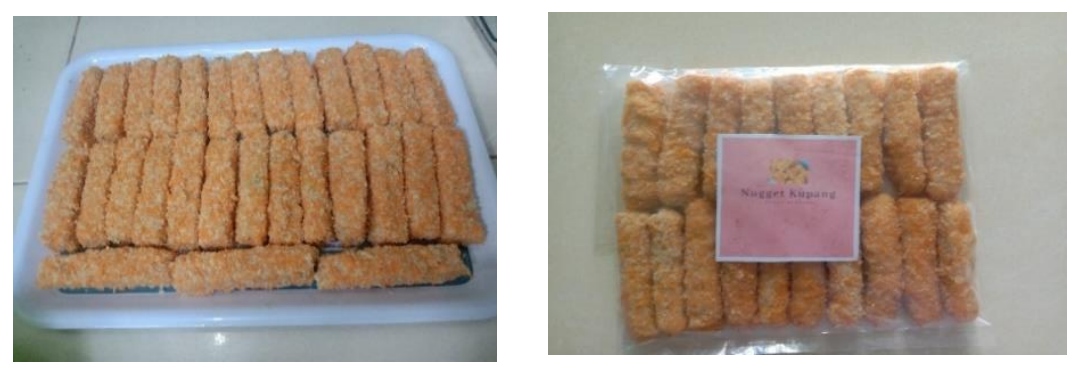

Gambar 5. Kemasan Nugget Kupang

c) Proses pemasaran

Penyampaian materi cara pemasaran produk berdasarkan hasil observasi berjalan dengan baik. Proses terakhir yang disampaikan pada pelatihan ini yaitu cara memasarkannya. Adapun cara memasarkan nugget yang dapat dilakukan yaitu dengan mempromosikan di sosial media seperti facebook, dengan promosi antar tetangga, menjual ke grosir, dan bisa juga dijual dengan keadaan sudah di goreng, dengan membuka gerai kecil-kecilan di depan rumah.

\section{PEMBAHASAN}

Berdasarkan data-data dan hasil penelitian, peneliti menyimpulkan bahwa pemberdayaan ibu rumah tangga melalui pembuatan nugget kupang di dusun XIII Pematang Delik yaitu:

\section{Tahap perencanaan}

Dari proses perencanaan yang dilakukan pada hari Minggu 25 April 2021 ditentukan bahwa pada pelatihan ini dilakukan di rumah Bu Linda pada Jumat 30 April 2021 yang diikuti oleh 14 ibu rumah tangga yang ada di dusun XIII Pematang Delik. Pelatihan juga disertai dengan pemilihan bahan baku yang baik, penyampaian materi cara pengemasan dan cara pemasaran nugget kupang.

\section{Tahap pelaksanaan}

Pemberdayaan ibu rumah tangga melalui pelatihan pembuatan nugget kupang yang dilaksanakan di dusun XIII Pematang Delik sejauh ini sudah terlaksana. Materi pelatihan yang disampaikan seperti pemilihan bahan baku yang baik, kemudian cara pengolahan kupang menjadi nugget, praktek pengemasan, sampai dengan penyampaian cara pemasarannya sudah terlaksana. Hal ini sesuai dengan hasil wawancara yang dilakukan peneliti terhadap informan yang mengikuti pelatihan pembuatan nugget kupang, dan informan dapat menjelaskan kembali bagaimana cara pengolahan nugget kupang. Kemudian peneliti juga melihat langsung pemahaman yang dimiliki peserta pelatihan saat pelatihan sedang berlangsung. Proses pemberdayaan dilakukan oleh instruktur yang sekaligus menjadi peneliti secara demonstrasi, dimana instruktur terlebih dahulu menyampaikan pemilihan bahan baku yang baik, kemudian mendemonstrasikan cara-cara yang digunakan dalam mengolah kupang menjadi nugget dan diikuti oleh peserta pelatihan, prakterk pengemasan nugget dan penyampaian cara pemasaran produk yang bisa dilakukan oleh ibu rumah tangga di dusun XIII Pematang Delik. Proses pemberdayaan ini mampu mengajarkan peserta secara efektif karena mudah dilakukan dan dibantu dengan berbagai perlengkapan seperti alat, bahan, petunjuk dan lain-lain. Proses pemberdayaan dalam pelatihan memiliki dampak positif terhadap peserta. Hal ini terlihat pada perubahan pengetahuan dan keterampilan serta tingkah laku 
peserta pelatihan dalam mengolah kupang menjadi nugget. Kemudian ini selanjutnya akan dinilai pada tahap evaluasi melalui hasil pelatihan yang diperoleh.

\section{Tahap Evaluasi}

Hasil pemberdayaan ibu rumah tangga melalui pelatihan pembuatan nugget kupang diukur dengan menilai keterampilan yang mereka kuasai setelah pelatihan diberikan. Evaluasi dilakukan dalam mengetahui segala proses yang telah dilakukan dari awal sampai akhir. Pada dasarnya, evaluasi dilakukan untuk mengetahui tingkat pemahaman peserta pelatihan terhadap materi yang telah diberikan evaluasi yang dilakukan dalam pelatihan pembuatan nugget kupang dilakukan setelah materi tuntas diberikan. Pada tahap evaluasi diketahui hambatan yang terjadi pada tahap pelaksanaan pelatihan yaitu pada proses pemotongan nugget yang harus sesuai dengan ukuran dan sesuai pembagian modal dan keuntungan yang dihasilkan.

Pemberdayaan yang telah dilaksanakan berjalan dengan baik, pelatihan ini memberikan dan menunjukkan perubahan bertambahnya pengetahuan dan keterampilan yang nantinya dapat membantu dalam memenuhikebutuhannya.

\section{SIMPULAN}

Berdasarkan hasil penelitian dan pembahasan yang telah penulis lakukan tentang pemberdayaan ibu rumah tangga melalui pelatihan pembuatan nugget kupang di dusun XIII Pematang Delik, maka dapat diambil kesimpulannya, yaitu:

1. Deskripsi hasil penelitian mengenai proses pemberdayaan ibu rumah tangga dilakukan melalui tahap perencanaan yaitu: dalam kegiatan persiapan, seluruh peserta menyiapkan kebutuhan keselamatan kerja dan alat perlengkapan dengan baik sesuai kebutuhan. Hal ini menunjukkan bahwa mulai ada kesadaran dari sasaran pemberdayaan untuk mampu memberdayakan dirinya terkait keselamatan kerja dan kebutuhan akan peralatan.

2. Deskripsi hasil penelitian mengenai proses pemberdayaan ibu rumah tangga pada tahap pelaksanaan yaitu: dalam hal pelaksanaan, peserta mulai memasuki tahap transformasi kemampuan berupa wawasan pengetahuan, kecakapan dan keterampilan dalam mengolah kupang menjadi nugget sehingga dapat berperan dalam pembangunan.

3. Deskripsi hasil penelitian mengenai proses pemberdayaan ibu rumah tangga pada tahap evaluasi yaitu: bahwa hambatan pada proses pembuatan nugget kupang yaitu pada saat pemotongan nugget harus sesuai ukuran pembagian dan harus sesuai dengan modal dan keuntungan.

\section{SARAN}

saran dari penulis yang kiranya dapat dijadikan pertimbangan dan masukan untuk pihakpihak yang terkait.

1. Untuk para peserta pelatihan diharapkan terus mengembangkan potensi yang ada dengan tersu belajar dan berinovasi dalam mengolah hasil laut.

2. Pemerintah desa sebaiknya lebih memperhatikan potensi yang ada disekitar yang bisa dikembangkan yang nantinya dapat bermanfaat bagi masyarakat dalam menambah pendapatan keluarga dan memberikan motivasi kepada masyarakat agar meningkatkan jiwa kewirausahaan.

3. Perlu adanya mitra yang dapat membantu memasarkan produk yang dibuat oleh masyarakat 


\section{DAFTAR PUSTAKA}

Anwar. 2006. Perencanaan Dan Pengembangan Manajemen Sumber Daya Manusia. Bandung: PT. Refika Aditama

Kamil, Mustofa. 2007. Andragogi. Bandung: Pedagogiana Press

Kamil, Mustofa. 2012. Model Pendidikan Pelatihan (Konsep dan Aplikasi). Bandung: Alfabeta

Mardikanto, Totok \& Poerwoko Soebianto. 2017. Pemberdayaan Masyarakat Dalam Perspektif Kebijakan Publik. Bandung: Alfabeta

Moleong, Lexy J. 2009. Metodologi Penelitian Kualitatif. Bandung: PT Remaja Rosdakarya.

Nasution, S .2003.Metodologi Penelitian Naturalistik Kualitatif. Bandung: Tarsiko

Saugi, Wildan \& Sumarno. 2015. Pemberdayaan Perempuan Melalui Pelatihan Pengolahan bahan Pangan Lokal. Jurnal Pendidikan dan Pemberdayaan Masyarakat volume 2 nomor 2 (226-238). http://journal.ac.id/index.php/jppm. Diakses pada 24 september 2020 pukul 08:52

Sudirman, 2014, Manajemen Pelatihan, Medan, UNIMED PRESS.

Sugiyono. 2012. Memahami Penelitian Kualitatif Cet. Ke-1. Bandung: Al-Fabeta

Suharto, Edi. 2010. Membangun Masyarakat Memberdayaka Rakyat. Bandung: Refika Aditama

Suharto, Edi. 2010. Membangun Masyarakat Memberdayaka Rakyat. Bandung: Refika Aditama

Teguh, Ambar S. 2004. Kemitraan dan Model-Model Pemberdayaan.Yogyakarta: Gava Media 